\title{
Covid 19 efecto en la rentabilidad y el rendimiento: El caso del sistema bancario en el Perú, 2019-2020
}

\section{Covid 19 impact in profitability and performance: The case of banking system in Peru, 2019-2020}

\author{
Carlos González Taranco ${ }^{1}$, Víctor Josué Álvarez Quiroz ${ }^{2}$
}

\begin{abstract}
Aim of this research is evaluate global pandemic due COVID 19 impact in peruvian banking system profitability and performance, period July 2019 - June 2020. Data Panel model has been applied to verify profitability twice with ROA and ROE as dependent variables. Independent variables $C A R_{i t}, L D R_{i t}$ and $N I M A_{i t}$ have a statistically significant positive impact to $R O A_{i t}$ and $R O E_{i t}$; and $O E F M_{i t}$ variable has a statistically significant negative impact to $R O A_{i t}$ and $R O E_{i t}$. $R O A_{i t}$ of most of banks have dropped since $2 \%$ and $2.5 \%$ have converged at an average of $1.8 \%$ in June 2020 . Related to $R O E_{i t}$ most of the banks have converged in a range within $10 \%$ and $15 \%$ in June 2020 .
\end{abstract}

Keywords: banking system, profitability, financial ratios, data panel model, COVID 19

\section{RESUMEN}

El objetivo de esta investigación es evaluar la pandemia global por impacto de COVID 19 en la rentabilidad y desempeño del sistema bancario peruano, período julio 2019 - junio 2020. Se ha aplicado el modelo de Panel de Datos para verificar la rentabilidad en dos ocasiones con ROA y ROE como variables dependientes. Las variables independientes $C A R_{i t}, L D R_{i t}$ y NIMA impacto positivo estadísticamente significativo en $R O A_{i t}$ y $R O E_{i t}$; y la variable $O E F M_{i t}$ tiene un impacto negativo estadísticamente significativo en $R O A_{i t}$ y $R O E_{i t}$. El $R O A_{i t}$ de la mayoría de los bancos ha caído desde que el $2 \%$ y el $2,5 \%$ convergieron a una media del $1,8 \%$ en junio de 2020 . En relación con el $R O E_{i t}$, la mayoría de los bancos han convergido en un rango entre el $10 \% y$ el $15 \%$ en junio de 2020 .

Palabras clave: sistema bancario, rentabilidad, ratios financieros, modelo de panel de datos, COVID 19

Received: 3 de agosto del 2020

Accepted: 16 de octubre de 2020

\section{Introducción}

Actual global pandemic context has affected global GDP, which means deeply recession and crisis in every country; however, most of the economics analysts has focused in real sector effects. Certainly present crisis context implies economics effects in real and monetary sector; in that sense purpose of this paper is, analyze effects of COVID 19 in the present economic context in profitability and performance of the peruvian banking system, since July 2019 until June 2020.

In Peru, as a part of First Generation Reforms applied in 90's were issued a Legislative Decree No. 770 at October 28th 1992, which modified Banks Law after 60 years.

Those modifications were basically about financial market liberalization, foreign capital opened, multiple banking then they are authorized to execute commercial, financial and mortgage operations, in addition were created Deposits Insurance Fund and Risks Central. (Gomez, J.C., 2000) (Morris, F. 2003).

As consequence of Russia Crisis Peruvian Government issued a Financial System Consolidation Program with the purpose to promote mergers and financial supporting, so that number's banks decreased since 25 in 1998 to 15 until 2003, later dropped to 11 in 2007, and nowadays they are 15 banks. (Castillo, P. y Barco, D., 2009) (Jopen,
G.; 2013) In present peruvian banking system comprises following banks: Banco de Credito del Peru, BBVA, Scotiabank, Interbank, Comercio, Pichincha, Mibanco, Citibank, Interamericano de Finanzas, Santander, Ripley, Falabella, GNB, Azteca, ICBC.

Through Supreme Decree No. 008-2020-SA, published on March 11, 2020, declares a National Health Emergency due global pandemic COVID 19. In that sense Period selected in order this research is July 2019 until June 2020.

Return on Assets (ROA) ratio (see Figure 1) shows that Citibank is on the top with $3 \%$ and it hold constant, and the other hand Chinese bank ICBC has increased since October 2019 until February 2020 and later keeps quite stable with $1.5 \%$ in average.

Pichincha, GNB and Finance Interamerican Bank (BANBIF) have kept stable along whole period within a range of $0.5 \%$ and $1 \%$. Other banks have started to decrease their ROA

${ }^{1}$ Universidad de San Martín de Porres, Perú. E-mail:cgonzalezt1@usmp.pe ${ }^{2}$ Universidad San Ignacio de Loyola, Perú. E-mail:victor.alvarez@usil.pe

How to cite: González Taranco, C., \& Álvarez Quiroz, V. J. (2021). Covid 19 efecto en la rentabilidad y el rendimiento: El caso del sistema bancario en el Perú, 2019-2020. ANÁLISIS ECONÓMICO Y FINANCIERO, 4(1), 07-14. https://doi.org/10.24265/raef.2021.v4n1.28 
since $2 \%$ and $2.5 \%$ converge at an average of $1.8 \%$. Only one bank with negative ROA is Azteca Bank since November 2019 and has dropped until -3.30 in June 2020.

The five leader banks evaluated through $R O E_{i t}$ with upper ratio to $20 \%$ stand out Citibank, Interbank, BCP, Mibanco and BBVA, according the Figure 2. Since February 2020, most of the banks have converged in a range within $10 \%$ and $15 \%$. Citibank is the only one bank that has kept a steady ratio of $22 \%$ during whole period.

We observe that Falabella Bank has dropped since $11 \%$ in February 2020, to $3 \%$ in June 2020. On the other hand, we observe (ROA) ratio (see Figure 3) where Azteca Bank present a serious drop of profitability with negative ratios since November 2019 with -1\% until June 2020 with $15.66 \%$.

One ratio to assess banking performance in international trade and financial derivative operations is the Off Balance Operations ratio measured as a relationship between Passive Contingency account divided by Total Assets.

From 15 banks just 4 of them has Off Balance ratio upper to 1: Credit, Ripley, Falabella and Santander Banks. Most of the banks converge in a range within 0.4 and 0.8. Comercio, Azteca, Mibanco and GNB Banks have a ratio within a range between 0.1 and 0.4 . Which means that peruvian banking system is quite conservative and therefore quite solvent in this global Recession context.

\section{Literature review}

Buchory (2016) analyzed the determinant factors of banking profitability in Indonesian Regional Development Banks. Descriptive and verification methods were taken on secondary data from 26 financial statements (p.308).

The data analysis technique used in this study is multiple linear regression, whose linear equation is:

$R O A=a+\beta_{1} R O A+\beta_{2} C A R+\beta_{3} N I M+\beta_{4} O E O I+\beta_{5} N P L+e$

Those ratios "were obtained from the Indonesian Banking Statistics Volume 13 No. 1 December, 2014." (p. 311). Authors found that LDR, CAR and NIM have not significant on ROA; the amount of contribution of all variables to $\backslash$ the dependent variable of ROA is $57.4 \%$ while the remaining $42.6 \%$ thought to be influenced by other variables not examined in this study" (p. 316).

Moore, G., Paskelian, O., Bell, S., \& Creek, J. (2019) wrote an analysis of chinese banking system, which comprises 42 banks, about its structure authors commented:

"The banking system in China has evolved and currently contains a mixture of banks with different types of ownership concentrations with the Big Four banks being completely owned by the government. There are also mixed-ownership banks where the government has varying degrees of ownership but other local shareholders are also present. In addition, there are banks which have varying degrees of foreign ownership" (Lin and Zhang, 2009).(p. 105).

Paper's objective is "evaluate the Chinese government, foreign investors and private investors' financial impact upon chinese banking performance" (p. 104).
Researchers investigate determinants of profitability using Ordinary Least Square (OLS) and applying three different specifications, considering dependent variable: ROA, ROE and NIM and independent variables: financial statements variables and ownership variables.

Authors concluded, "that relatively high government ownership has a negative impact on the Chinese bank performance measures. Similarly, the presence of higher levels of foreign ownership and private ownership in Chinese leads to relatively higher performance measures" (p. 112).

Lardic, S., \& Terraza, V. (2019) studied germany banking performance applying Financial Ratios, being their objective: "measure banks performance according to their specialization in order to analyze groups of banks and their disparities in determination of a bank performance" (p.23).

Authors evaluated 1624 banks performance lin order to analyze groups of banks and their disparities in determination of a bank performance" about \commercial banks, cooperative banks and saving banks in Germany over the years from 2000 to 2014" (p. 23).

Model comprises ratios about profitability measures (ROAA, ROAE), Total Assets, Capital measures, Liquidity measures, Off Balance ratio (Lardic \& Terraza, 2019, p.35).

Model applied in this research is data panel, authors used the system GMM estimator (SYS-GMM) (Blundell and Bond, 1998; Blundell et al., 2001). This method uses a set of instrumental variables to solve the endogeneity problem arising from the potential correlation between the error term and the independent variable in dynamic panel data models" (Lardic \& Terraza, 2019, p.29).

Model formula considered ROAA and ROAE as dependent variables, they were evaluated simultaneously, and they found differences between three groups of banks.

\section{Objectives and hypothesis}

This research has the following objectives:

General objective: Evaluate global pandemic due COVID 19 impact in peruvian banking system profitability and performance.

Specific objective: Profitability of the peruvian banking system is explained by financial ratios: CAR, NPGL, OEFM, FITI, LDR and OFFBAL.

General hypothesis: Global pandemic (COVID 19) has affected negatively to peruvian banking system profitability and performance.

Specific hypothesis comprises the following:

- H1: CAR positively affects ROA and ROE

- H2: NPGL negatively affects ROA and ROE

- H3: OEFM negatively affects ROA and ROE

- H4: FITI positively affects ROA and ROE

- H5: LDR positively affects ROA and ROE

- H6: OFFBAL positively affects ROA and ROE

- H7: NIM positively affects ROA and ROE. 


\section{Variables}

This research comprises following variables:

- ROA : Return on assets, expressed by the ratio between the net income and average total assets.

- ROE : Return on equity, expressed by the ratio between the net income and average shareholders equity.

- CAR : Capital adequacy ratio, expressed by the ratio between bank's capital and total risk-weighted assets and contingents.

- NPGL : Ratio calculated as non-performing loan portfolio divided by gross loans.

- OEFM : Ratio calculated as operational expenses divided by total interest margin.

- FITI: Ratio calculated as financial income divided by total income.

- LDR : Ratio calculated as loans divided by deposits.

- OFFBAL: Ratio calculated as contingent divided by total assets.

- NIM : Ratio calculated as net interest margin divided by total assets.

Those ratios were taken from Statistics published monthly by Superintendence of Banking, Insurance and Private Pension Funds, corresponding to the period July 2019 to June 2020. Exception about LDR, OFFBAL and NIM, whose were calculated from financial statements per every bank.

\section{Method}

Method applied in this research is data panel model with effects relative the cross-section elements or individuals (the banks) to analyze the causal relations between the most relevant financial ratios which shows the performance of the peruvian banking system (Larios-Meoño et al., 2016). Profitability of the peruvian banking system has been evaluated twice, considering as dependent variable ROA and ROE.

Cameron and Trivedi (2005) explain the individual-specific fixed effects model in the next equations applied for our research:

$$
\begin{aligned}
R O A_{i t} & =\delta_{i}+x_{i t}^{\prime} \beta+\epsilon_{i t} i=1, \cdots, 15 t=1, \cdots, 12 \\
R O E_{i t} & =\phi_{i}+x_{i t}^{\prime} \theta+v_{i t} i=1, \cdots, 15 t=1, \cdots, 12
\end{aligned}
$$

Where

$$
x_{i t}=\left[\begin{array}{c}
1 \\
\text { CAR }_{i t} \\
\text { NPGL }_{i t} \\
\text { OEFM }_{i t} \\
\text { FITI }_{i t} \\
\text { LDR }_{i t} \\
\text { OFFA } \\
\text { NIM } \\
\text { NIt } \\
\left(C O V I D_{i t}\right)\left(O E F M_{i t}\right)
\end{array}\right], \beta=\left[\begin{array}{c}
\beta_{1} \\
\beta_{2} \\
\beta_{3} \\
\beta_{4} \\
\beta_{5} \\
\beta_{6} \\
\beta_{7} \\
\beta_{8} \\
\beta_{9}
\end{array}\right], \theta=\left[\begin{array}{c}
\theta_{1} \\
\theta_{2} \\
\theta_{3} \\
\theta_{4} \\
\theta_{5} \\
\theta_{6} \\
\theta_{7} \\
\theta_{8} \\
\theta_{9}
\end{array}\right]
$$

Then we continue the fixed effects transformation (Wooldridge, 2010) defining the following average variables over time relative to equation 1 :

$$
\begin{aligned}
& \overline{R O A}_{i}=\frac{\sum_{t=1}^{12} R O A_{i t}}{12}
\end{aligned}
$$

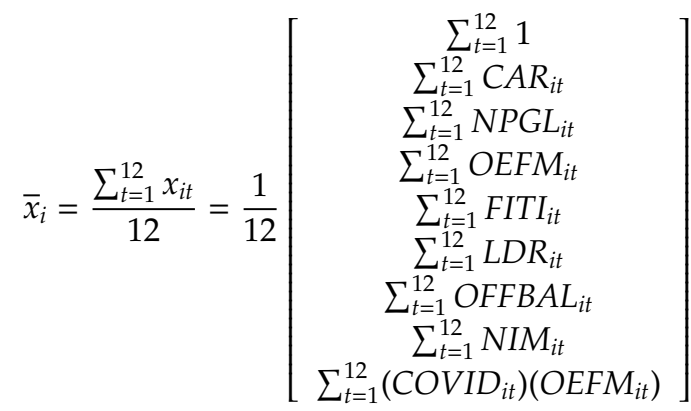

$$
\begin{aligned}
& \bar{e}_{i}=\frac{\sum_{t=1}^{12} e_{i t}}{12}
\end{aligned}
$$

Considering the equations 3,4 and 5 we formulate the following cross-section equation:

$$
\overline{R O A}_{i}=\delta_{i}+\bar{x}_{i} \beta+\bar{e}_{i} \quad i=1,2, \cdots, 15
$$

Subtracting equation 6 from equation 1, according to Pesaran (2015) we obtain the Fixed Effects Model (FEM):

$R O A_{i t}-\overline{R O A}_{i}=\left(x_{i t} \bar{x}_{i}\right)^{\prime} \beta+\left(\epsilon_{i t} \bar{e}_{i}\right) \quad i=1,2, \cdots, 15 t=1,2, \cdots, 12$

Using the estimation method of parameters Ordinary Least Squares (OLS) to FEM in equation 7 we obtain the Fixed Effects Estimator $\hat{\beta}$ :

$\hat{\beta}=\left[\sum_{i=1}^{15} \sum_{t=1}^{12}\left(x_{i t}-\bar{x}_{i}\right)\left(x_{i t}-\bar{x}_{i}\right)^{\prime}\right]^{-1} \sum_{i=1}^{15} \sum_{t=1}^{12}\left(x_{i t}-\bar{x}_{i}\right)\left(R O A_{i t}-\overline{R O A}_{i}\right)$

Establishing the estimation property by OLS fitted regression in the model in equation 6 passes through the point of the means of the variables, then:

$$
\hat{\delta}_{i}=\overline{R O A}_{i}-\bar{x}_{i} \hat{\beta}, \quad i=1,2, \cdots, 15
$$

\section{Results}

Table 1 shows three Banks with higher Average ROA are Citibank 3.37\%, Mibanco 2.85\%, BCP 2.46\%. Three banks with lower Average ROA are ICBC 1.04\%, GNB 0.82\% and Azteca $1.57 \%$.

Three Banks with higher Average ROE are Citibank 22.43\%, Interbank 20.67\% and Credit Bank 19.13\%. Three banks with lower Average ROE are Pichincha Bank 5.84\%, ICBC 5.23\% and Azteca Bank 6.88\%.

Three Banks with higher Off Balance ratio are: Citibank 1.93\%, Ripley $1.81 \%$ and Falabella $1.37 \%$. Three Banks with lower Off Balance ratios are: Azteca 20.49\%, GNB 19.85\% and Comercio $10.01 \%$.

Table Table 2 shows existence of a strong negative correlation between $O E F M_{i t}$ and $R O E_{i t}$ variables equals to 
-0.71906, a weak positive correlation between $L D R_{i t}$ and $R O E_{i t}$ equals to 0.13849 and a weak negative correlation between $C A R_{i t}$ and $R O A_{i t}$ equals to -0.13339 .

The parameter estimators of the individual-specific fixed effects model to $R O A_{i t}$ in equation 1 (see Table 3), where the independent variables as NPGL $L_{i t}, F_{T T} I_{i t}, O f F B A L_{i t}$ do not explain $R O A_{i t}$ and the constant is not statistically significant at $5 \%$ significance level.

Independent variables $C A R_{i t}, L D R_{i t}$ and $N I M_{i t}$ have a statistically significant positive impact to $R O A_{i t}$, highlighting the $C A R_{i t}$ variable whose unity increase achieve to increase in 0.10 to $R O A_{i t}$ variable. It is necessary to specify thatOEFM $M_{i t}$ variable has a statistically significant negative impact to $R O A_{i t}$ considering the periods when the pandemic hit Peru the unity increase of $O E F M_{i t}$ variable impacts negatively to $R O A_{i t}$ variable decreasing it by 0.05 .

The residuals of the model present normal probability distribution due to probability value of Jarque-Bera statistic is greater than $5 \%$ significance level. We found no redundant cross-section effects through probability value of $\chi^{2}$-statistic with 14 degree of freedom is less than $5 \%$ significance level.

The model presents a good fit since adjusted- $R^{2}$ is close to unity and global significance of estimators because the probability value of F-statistic equals to zero is less than $5 \%$ significance level. The estimated variance of error is near to zero.

The individual-specific fixed effects model to $R O E_{i t}$ in equation 1 is also shown in Table 4, where the independent variables as $N P G L_{i t}, F I T I_{i t}$, OFFBAL $L_{i t}$ do not explain $R O E_{i t}$ due to individual statistical insignificance of the estimated coefficients at $5 \%$ significance level.

Also the following independent variables $C A R_{i t}, L D R_{i t}$ and $N I M_{i t}$ have a statistically significant positive impact to $R O E_{i t}$, highlighting the $C A R_{i t}$ variable whose unity increase achieve to increase in 0.37 to $R O E_{i t}$ variable followed by $N I M_{i t}$ variable whose unity increase produces an 0.26 increase in $R O E_{i t}$ variable.

Also is necessary to specify that only $O E F M_{i t}$ variable has a statistically significant negative impact to $R O E_{i t}$ reducing it by 0.30 for each unity increase of $O E F M_{i t}$ during the periods with absence of pandemic but $R O E_{i t}$ decreases in 0.04 effected to unity increase of $O E F M_{i t}$ during the state of emergency due to Covid-19 pandemic in Peru.

The residuals of the $R O E_{i t}$ model present normal probability distribution due to probability value of Jarque-Bera statistic is greater than $5 \%$ significance level. We found no redundant cross-section effects because the probability value of $\chi^{2}$ statistic with 14 degree of freedom is zero and is less than $5 \%$ significance level.

In the same way, the $R O e_{i t}$ model presents a good fit since adjusted- $R^{2}$ is close to unity and global significance of estimators because the probability value of F-statistic equals to zero is less than $5 \%$ significance level. The estimated variance of error is very low approximately equal to 0.02 .

As the estimated constant of the equation 1 is statistically zero, the cross-section fixed effects to $R O A_{i t}$ model (see Table 5) constitute the constants of the model for each bank, thus when the independent variables are zero then estimated average $R O A_{i t}$ is 0.02 to Citibank, 0.01 to Mibanco, and 0.02 roughly for both Azteca and ICBC; these results are consistent with the Figure 1.

According the cross-section fixed effects to $R O E_{i t}$ model also shown in Table 3, we observe that Mibanco has the higher estimated average $R O E_{i t}$ equals to 0.24 , followed by Citibank with 0.23, Interbank with 0.22 and BBVA and $\mathrm{BCP}$ with 0.21, considering all independent variables equals to zero in the $R O E_{i t}$ model; lastly, Azteca has the lowest estimated average $R O E_{i t}$ equals to half of the ICBC whose indicator is 0.04 , when the independent variables are zero in the model.

\section{Conclusions}

Considering Introduction, Problem Formulation, Objectives and Hypothesis, Method and Results, Conclusions are the following:

1. Our research has confirmed general and specific hypothesis and it has been confirmed trough a data panel model with a good fit since adjusted- $R^{2}$ is close to unity and global significance of estimators because the probability value of F-statistic equals to zero is less than $5 \%$ significance level. The model overcame tests of normality, multicollinearity, heteroscedasticity and autocorrelation.

2. Dummy variable COVID * OEFM was included to verify impact of operating expenses impact in banking performance due its down inflexibility in short term, and it's a statistical significance variable with -0.00516 applying ROA as dependent variable and -0.04068 applying $R O E$ as dependent variable.

3. Independent variables $C A R_{i t}, L D R_{i t}$ and $N^{\prime} M_{i t}$ have a statistically significant positive impact to $R O A_{i t}$. In addition $O E F M_{i t}$ variable has a statistically significant negative impact to $R O A_{i t}$ reducing it by 0.04883 for each unity increase of $O E F M_{i t}$ during period analyzed. NPGL, FITI and OFFBAL do not explain $R O A_{i t}$ and the constant is not statistically significant at $5 \%$ significance level.

4. Independent variables $C A R_{i t}, L D R_{i t}$ and $N I M_{i t}$ have a statistically significant positive impact to $R O E_{i t}$; besides just $O E F M_{i t}$ variable has a statistically significant negative impact to $R O E_{i t}$. Independent variables as NPGL $L_{i t}, F I T I_{i t}$, OFFBAL $L_{i t}$ do not explain $R O E_{i t}$ due to individual statistical insignificance of the estimated coefficients at 5\% significance level.

5. Cross-section fixed effects to $R O E_{i t}$ model shown in Table 3 constitute the constants of the model for each bank, thus when the independent variables are zero then estimated average $R O A_{i t}$ is 0.02 to Citibank, 0.01 to Mibanco, and -0.02 roughly for both Azteca and ICBC; these results are consistent with the Figure 1.

6. According cross-section fixed effects to $R O A_{i t}$ model, the estimated constant is statistically zero, then estimated average $R O A_{i t}$ is 0.02 to Citibank, 0.01 to Mibanco, and -0.02 roughly for both Azteca and ICBC. 
7. According the cross-section fixed effects to $R O E_{i t}$ model, Mibanco has the higher estimated average $R O E_{i t}$ equals to 0.24 , followed by Citibank with 0.23 , Interbank with 0.22 and BBVA and BCP with 0.21, considering all independent variables equals to zero in the $R O E_{i t}$ mode.

8. Lastly, Azteca has the lowest estimated average $R O E_{i t}$ equals to half of the ICBC whose indicator is 0.04 , when the independent variables are zero in the model.

9. Constants per $R O A_{i t}$ and $R O E_{i t}$ per banks according cross-section fixed effects are shown in Appendix. Related to constant ROE model all of them are positive, whose range vary from $10 \%$ to $23.8 \%$, with exception of ICBC Bank 4.29\% and Azteca Bank 1.84\%.

10. During period July 2019 until June 2020, Return on Assets $(R O A)$ ratio shows that Citibank is on the top with $3 \%$ and it hold constant; and most of the banks have dropped since $2 \%$ and $2.5 \%$ have converged at an average of $1.8 \%$ in June 2020 . Only one bank with negative $R O A$ is Azteca Bank since November 2019 and has dropped until $-3.30 \%$ in June 2020 .

11. Five leader banks evaluated through $R O E_{i t}$ with upper ratio to $20 \%$ stand out Citibank, Interbank, BCP, Mibanco and BBVA. Since February 2020, most of the banks have converged in a range within $10 \%$ and $15 \%$ in June 2020 . Citibank is the only one bank that have kept a steady ratio of $22 \%$ during whole period.

12. Ratio to assess banking performance in international trade and financial derivative operations is the Off Balance Operations ratio, which from 15 banks just 4 of them have a ratio upper to 1: Credit, Ripley, Falabella and Santander Banks. Which means that peruvian banking system is quite conservative and therefore quite solvent in this global recession context.

Global pandemic context has affected slightly peruvian banking system but its profitability and performance show that are solvent, because its equity multiplier average is higher than 6, which it means that it is recommended expand the analysis about its size, banking concentration level and evaluate optimum equity multiplier in a crisis context.

\section{Agradecimientos}

Los autores agradecen el apoyo del Instituto de Investigación de la Facultad de Ciencias Contables y Económicas y Financieras de la Universidad de San Martín de Porres.

\section{References}

Buchory, H. A. (2016). Determinants Of Banking Profitability In Indonesian Regional Development Bank. Aktual'Ni Problemy Ekonomiky = Actual Problems in Economics, (177), 308-318. Retrieved from https://search.proquest.com/docview/1781553728?accou ntid $=43847$

Cameron, A. C. and Trivedi, P. K. (2005). Microeconometrics: Methods and Applications. New York: Cambridge University Press.
Castillo, P. and Barco, D. (2009) Crisis Financieras y Manejo de Reservas en el Perú. En: Revista Estudios Económicos $N^{\circ}$ 17 del Banco Central de Reserva del Perú. Retrieved from: https://www.bcrp.gob.pe/docs/Publicaciones/RevistaEstudios-Economicos/17/Estudios-Economicos-17-3.pdf

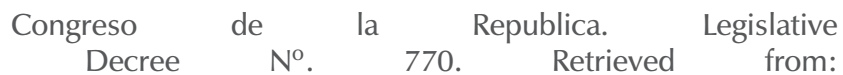
http://www.leyes.congreso.gob.pe/DetLeyNume1p.aspx $? \mathrm{xNorma}=3 \& \mathrm{xNumero}=770 \& \mathrm{xTipoNorma}=3$

Gómez, J. C. (2000) Proceso de consolidación del sistema bancario: fusiones, rentabilidad y competencia 19942000. En Publicaciones del BCRP. Recuperado de: https://www.bcrp.gob.pe/docs/Publicaciones/Documentosde-Trabajo/2000/Documento-Trabajo-12-2000.pdf

Jopen, G. (2013) Poder de mercado, intermediación financiera y banca: un enfoque de organización industrial. Economía, Review of Pontifical Catholic University of Peru, Vol. 36(71), pages 75-106. Retrieved from: https://ideas.repec.org/a/pcp/pucrev/y2013i71p75106.html

Lardic, S., and Terraza, V. (2019). Financial ratios analysis in determination of bank performance in the german banking sector. International Journal of Economics and Financial Issues, 9(3), 22-47. Retrieved from https://search.proquest.com/docview/2270050009?acco untid $=43847$

Larios-Meoño, J. F. ; González-Taranco, C. E. and ÁlvarezQuiroz, V. J. (2016). Investigación en Economía y Negocios: Metodología con Aplicaciones en EViews. Lima: Fondo Editorial USIL.

Mishkin, F. S., \& Eakins, S. G. (2018). Financial markets and institutions. Global Edition. Boston: Pearson. Retrieved from: http://dl.rasabourse.com/Books/Finance $\% 20$ and\%20Finan cial\%20Markets\%5BFredericS.Mishkin\%5DStanleyEakins FinancialMarketsandInstitutions\%28rasabourse.com\%29.pdf

Moore, G., Paskelian, O., Bell, S., and Creek, J. (2019). Does the government drive chinese banking performance $\{$ an analysis of the chinese banking system. The Journal of Applied Business and Economics, 21(7), 104-113. Retrieved from https://search.proquest.com/docview/2336304343?accoun $\mathrm{tid}=43847$

Morris, F. (2003) La Reforma del Sistema Financiero. Instituto Peruano de Economía Working Paper. Retrieved from http://www.ipe.org.pe/portal/wpcontent/uploads/2018/01/1999-La-Reforma-del-SistemaFinanciero.pdf

Pesaran, M. H. (2015). Time Series and Panel Data Econometrics. New York: Oxford University Press.

Superintendence of Banking, Insurance and Private Pension Funds (2020) Statistics. Multiple Banking, Financial Ratios.

Superintendence of Banking, Insurance and Private Pension Funds (2010) Registration of Indicators and Terms of the Financial System.

Wooldridge, J. M. (2002). Econometric Analysis of CrossSection and Panel Data. USA: The MIT Press. 
Tables and figures

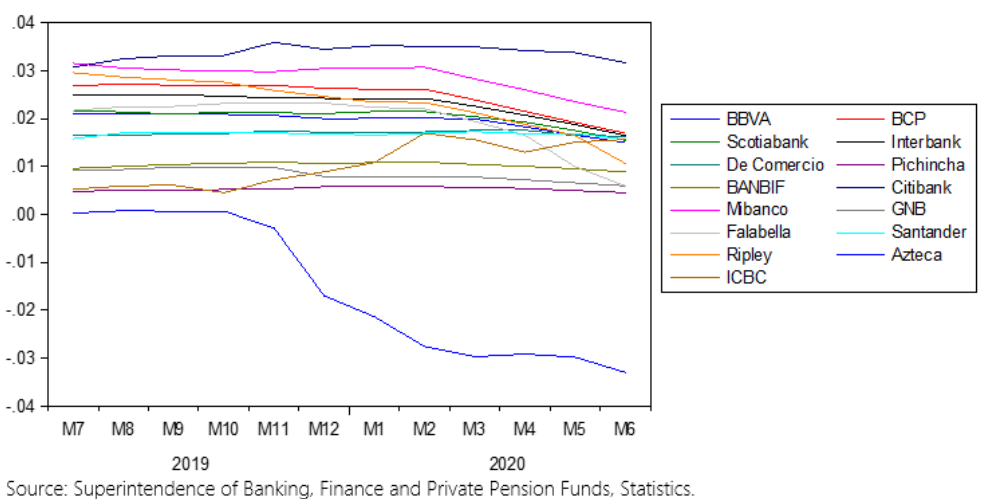

Figura 1. ROA OF PERUVIAN BANKING SYSTEM, Period July 2019-June 2020

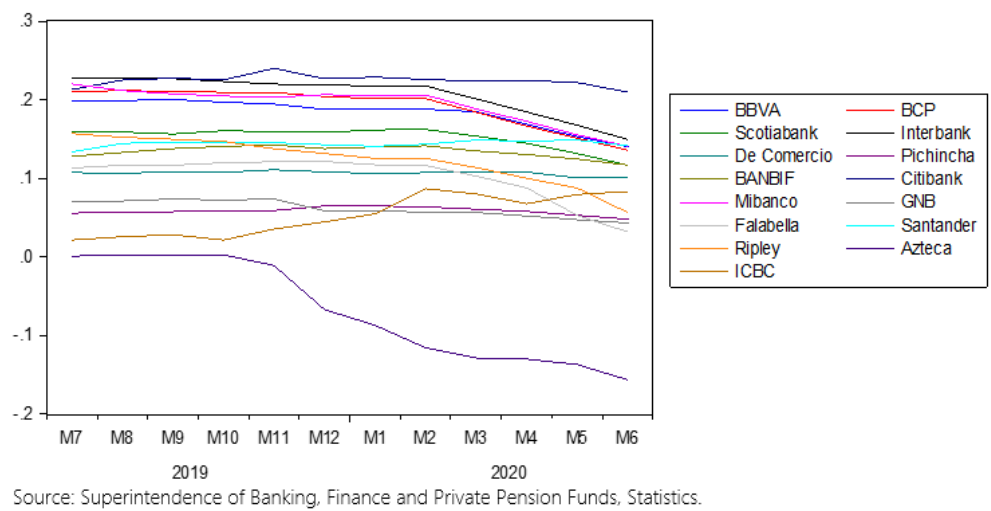

Figura 2. ROE OF PERUVIAN BANKING SYSTEM, Period July 2019-June 2020

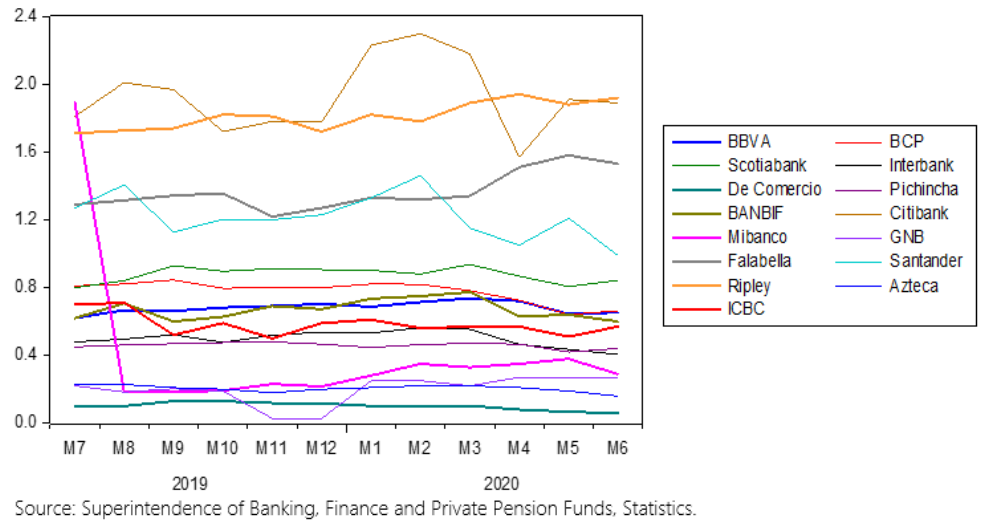

Figura 3. OFFBAL OF PERUVIAN BANKING SYSTEM, Period July 2019-June 2020 
Table №1: Descriptive statistics by bank

\begin{tabular}{ccccccccccc}
\hline- & & ROA & & & ROE & \multicolumn{3}{c}{ OFFBAL } \\
\hline BANKS & MEAN & MAX & MIN & MEAN & MAX & MIN & MEAN & MAX & MIN & OBS \\
BBVA & 0.01953 & 0.02114 & 0.01499 & 0.18317 & 0.20026 & 0.14022 & 0.68189 & 0.73693 & 0.62 & 12 \\
BCP & 0.02457 & 0.02711 & 0.01696 & 0.19127 & 0.21159 & 0.1359 & 0.77697 & 0.84579 & 0.64161 & 12 \\
Scotiabank & 0.02024 & 0.02151 & 0.01547 & 0.15177 & 0.16203 & 0.11653 & 0.87648 & 0.93695 & 0.8 & 12 \\
Interbank & 0.02291 & 0.025 & 0.01646 & 0.2067 & 0.22739 & 0.14928 & 0.49877 & 0.56351 & 0.40548 & 12 \\
De Comercio & 0.01694 & 0.01759 & 0.01632 & 0.10644 & 0.11066 & 0.10013 & 0.10079 & 0.13071 & 0.06 & 12 \\
Pichincha & 0.00526 & 0.00583 & 0.00452 & 0.05835 & 0.06467 & 0.04816 & 0.45909 & 0.48003 & 0.42 & 12 \\
BANBIF & 0.01023 & 0.01094 & 0.00885 & 0.13387 & 0.14243 & 0.11689 & 0.67057 & 0.77365 & 0.59956 & 12 \\
Citibank & 0.03371 & 0.03587 & 0.0307 & 0.22426 & 0.23988 & 0.20969 & 1.92837 & 2.29827 & 1.57 & 12 \\
Mibanco & 0.02854 & 0.03152 & 0.02134 & 0.19332 & 0.21986 & 0.14075 & 0.40659 & 1.89 & 0.18353 & 12 \\
GNB & 0.00825 & 0.00981 & 0.00596 & 0.06112 & 0.07362 & 0.04301 & 0.1985 & 0.27 & 0.02755 & 12 \\
Falabella & 0.01937 & 0.02325 & 0.00596 & 0.1014 & 0.12143 & 0.03179 & 1.36678 & 1.58 & 1.2194 & 12 \\
Santander & 0.01674 & 0.01727 & 0.01564 & 0.14386 & 0.14869 & 0.13362 & 1.21881 & 1.46 & 0.99 & 12 \\
Ripley & 0.02318 & 0.02958 & 0.01061 & 0.12358 & 0.157 & 0.05635 & 1.81304 & 1.94 & 1.71 & 12 \\
Azteca & -0.01566 & 0.00076 & -0.03298 & -0.06875 & 0.00278 & -0.15661 & 0.20489 & 0.23 & 0.16 & 12 \\
ICBC & 0.01041 & 0.01696 & 0.00454 & 0.05229 & 0.08678 & 0.02144 & 0.58333 & 0.71 & 0.5 & 12 \\
All & 0.01628 & 0.03587 & -0.03298 & 0.12418 & 0.23988 & -0.15661 & 0.78566 & 2.29827 & 0.02755 & 180 \\
\hline
\end{tabular}

Table $\mathbf{N}^{0} 2$ : Correlation matrix

\begin{tabular}{cccccccccc}
\hline & ROA & ROE & CAR & NPGL & OEFM & FITI & LDR & OFFBAL & NIM \\
\hline ROA & 1 & 0.9293 & -0.1334 & -0.5458 & -0.5665 & -0.3068 & 0.1444 & 0.4905 & -0.2014 \\
ROE & 0.9293 & 1 & -0.2708 & -0.5004 & -0.7191 & -0.2828 & 0.1383 & 0.3829 & -0.287 \\
CAR & -0.1334 & -0.2708 & 1 & -0.3088 & 0.1384 & -0.2094 & -0.6782 & 0.0019 & 0.0419 \\
NPGL & -0.5458 & -0.5004 & -0.3088 & 1 & 0.636 & 0.5704 & 0.3375 & -0.4856 & 0.5628 \\
OEFM & -0.5665 & -0.7191 & 0.1384 & 0.636 & 1 & 0.2685 & 0.1745 & -0.2598 & 0.5956 \\
FITI & -0.3068 & -0.2828 & -0.2094 & 0.5704 & 0.2685 & 1 & 0.3698 & -0.5151 & 0.2235 \\
LDR & 0.1444 & 0.1383 & -0.6782 & 0.3375 & 0.1745 & 0.3698 & 1 & -0.1025 & 0.117 \\
OFFBAL & 0.4905 & 0.3829 & 0.0019 & -0.4856 & -0.2598 & -0.5151 & -0.1025 & 1 & -0.0606 \\
NIM & -0.2014 & -0.287 & 0.0419 & 0.5628 & 0.5956 & 0.2235 & 0.1170 & -0.0606 & 1 \\
\hline
\end{tabular}

Table $N^{\circ}$ 3: ROA and ROE Fixed Effects Models.

\begin{tabular}{|c|c|c|c|c|}
\hline \multirow[t]{2}{*}{ VARIABLE } & $\mathrm{ROA}$ & \multicolumn{3}{|c|}{ ROE } \\
\hline & ESTIMATOR & PROB(t-STAT) & ESTIMATOR & PROB(t-STAT) \\
\hline CAR & 0.09759 & 0.0000 & 0.36663 & 0.0011 \\
\hline NPGL & -0.03216 & 0.6331 & -0.11166 & 0.7444 \\
\hline OEFM & -0.04883 & 0.0000 & -0.29852 & 0.0000 \\
\hline FITI & 0.00086 & 0.9183 & -0.03866 & 0.3676 \\
\hline LDR & 0.01738 & 0.0002 & 0.07909 & 0.0009 \\
\hline OFFBAL & -0.00016 & 0.9209 & 0.00305 & 0.7018 \\
\hline NIM & 0.05588 & 0.0000 & 0.25635 & 0.0000 \\
\hline COVID*OEFM & -0.00516 & 0.0000 & -0.04068 & 0.0000 \\
\hline Constant & 0.00458 & 0.6669 & 0.15402 & 0.0049 \\
\hline Adjusted R-squared & 0.94191 & & 0.96311 & \\
\hline Standard Error of Regression & 0.00295 & & 0.0150 & \\
\hline F-statistic & 132.9346 & & 213.4194 & \\
\hline Prob. (F-statistic) & 0.00000 & & 0.000000 & \\
\hline Residuals Jarque-Bera & 5.93409 & & 4.14346 & \\
\hline Prob. (Resid. Jarque-Bera) & 0.05146 & & 0.12597 & \\
\hline Redundant (Cross-section $\chi_{14}^{2}$ ) & 365.95618 & & 405.64029 & \\
\hline Prob. (Redun. Cross-section $\chi_{14}^{2}$ & 0.00000 & & 0.00000 & \\
\hline
\end{tabular}

\footnotetext{
Source: Authors
} 
Table N ${ }^{\circ}$ 4: Cross-Section Fixed Effects (Dummy Variables) in ROA and ROE Models.

\begin{tabular}{ccc}
\hline BANKS & ROA EFFECTS & ROE EFFECTS \\
\hline BBVA & 0.00266 & 0.0479 \\
BCP & 0.00638 & 0.04745 \\
Scotiabank & 0.00051 & 0.00128 \\
Interbank & 0.00369 & 0.06204 \\
De Comercio & 0.00346 & 0.00117 \\
Pichincha & -0.00464 & -0.03185 \\
BANBIF & -0.00471 & 0.00948 \\
Citibank & 0.01647 & 0.07972 \\
Mibanco & 0.01341 & 0.08377 \\
GNB & -0.00447 & -0.04591 \\
Falabella & 0.00866 & 0.0065 \\
Santander & -0.00201 & -0.00329 \\
Ripley & 0.0041 & -0.01151 \\
Azteca & -0.02483 & -0.13558 \\
ICBC & -0.01869 & -0.11116 \\
\hline Source: Authors & &
\end{tabular}

ANEXO: Table A1. Constant in ROA and ROE Models.

\begin{tabular}{ccc}
\hline BANKS & CONSTANT ROA MODEL & CONSTANT ROE MODEL \\
\hline BBVA & 0.04790 & 0.20192 \\
BCP & 0.04745 & 0.20146 \\
Scotiabank & 0.00128 & 0.15529 \\
Interbank & 0.06204 & 0.21605 \\
De Comercio & 0.00117 & 0.15519 \\
Pichincha & -0.03185 & 0.12217 \\
BANBIF & 0.00948 & 0.16350 \\
Citibank & 0.07972 & 0.23373 \\
Mibanco & 0.08377 & 0.23778 \\
GNB & -0.04591 & 0.10811 \\
Falabella & 0.00650 & 0.16051 \\
Santander & -0.00329 & 0.15072 \\
Ripley & -0.01151 & 0.14251 \\
Azteca & -0.13558 & 0.01843 \\
ICBC & -0.11116 & 0.04286 \\
\hline Source: Author
\end{tabular}

Source: Authors 